\title{
Inhibition of Protein Kinase $M \zeta$ Disrupts the Stable Spatial Discharge of Hippocampal Place Cells in a Familiar Environment
}

\author{
Jeremy M. Barry, ${ }^{1,2}$ Bruno Rivard, ${ }^{1,2}$ Steven E. Fox, ${ }^{1,2}$ Andre A. Fenton, ${ }^{1,2,3}$ Todd C. Sacktor, ${ }^{1,2}$ and Robert U. Muller ${ }^{1,2}$ \\ ${ }^{1}$ Department of Physiology and Pharmacology, State University of New York, Downstate Medical Center, Brooklyn, New York 11203, ${ }^{2}$ The Robert F. \\ Furchgott Center for Neural \& Behavioral Science, State University of New York, Downstate Medical Center, Brooklyn, New York 11203, and ${ }^{3}$ Center for \\ Neural Science, New York University, New York, New York 10003
}

It is widely held that spatial computations in the rodent hippocampus require the location-specific discharge of place cells that together form a stable cognitive map used to solve and perform spatial tasks. It is not known, however, if map stability requires persistent hippocampal synaptic strength changes that are vulnerable to blockade of protein kinase $\mathrm{M} \zeta(\mathrm{PKM} \zeta$ ) phosphorylation activity, a manipulation that reverses hippocampal LTP and disrupts multiple forms of long-term memory. Here we report that acute intrahippocampal inhibition of PKM $\zeta$ disrupts place cell activity in a familiar environment, where the map is expected to be stable. After this disruption, new, stable spatial firing patterns can later form, but the new and original maps are unrelated even though the rat is exposed to a constant environment. We therefore propose that the previously demonstrated erasure of stored spatial memory and the disruption of place cell firing are parallel effects of PKM $\zeta$ blockade. We similarly propose that the known sparing of new spatial memory formation depends on the sparing of new map formation. On these bases, we argue that the loss of the map used to perform a practiced spatial task leads to behavioral performance deficits, and that synaptic plasticity maintained by PKM $\zeta$, which stabilizes the map, is essential for the proper expression of spatial memory.

\section{Introduction}

The ensemble location-specific discharge of hippocampal place cells is believed to reflect the operation of a spatial map of the environment that enables rodents to solve complex spatial problems (O'Keefe and Nadel, 1978); interference with locationspecific firing, however induced, leads to parallel performance deficits in spatial tasks (McHugh et al., 1996; Barnes et al., 1997; Cho et al., 1998; Kentros et al., 1998, 2004; Ekstrom et al., 2001; Liu et al., 2003; Nakazawa et al., 2004). It is also agreed that the map is environment-specific; when the same cells are recorded in sufficiently different circumstances, their individual firing fields appear unrelated. Moreover, because a particular map is reactivated whenever the animal returns to a particular environment, it is inferred that map stability requires the presence of a memory mechanism (Muller et al., 1987).

In support of this inference, it is known that genetically altering biochemical pathways required for normal hip-

Received Jan. 22, 2012; revised July 26, 2012; accepted July 29, 2012.

Author contributions: J.M.B., S.E.F., A.A.F., and R.U.M. designed research; J.M.B and R.U.M. performed research; J.M.B., B.R., and R.U.M. contributed unpublished reagents/analytic tools; J.M.B., S.E.F., A.A.F., and R.U.M. analyzed data; J.M.B., A.A.F., T.C.S., and R.U.M. wrote the paper.

This work was funded by National Institutes of Health Grants MH057068, MH053576 and DA034970 to T.C.S. and NS20686 to R.U.M. We thank Dr. John Kubie for discussions concerning experimental design.

The authors declare no competing financial interests.

Correspondence should be addressed to Dr. Robert U. Muller, Department of Physiology and Pharmacology, Downstate Medical Center, 450 Clarkson Ave., Brooklyn, NY 11203. E-mail: bob.muller@downstate.edu.

DOI:10.1523/JNEUROSCI.0319-12.2012

Copyright $\odot 2012$ the authors $\quad 0270-6474 / 12 / 3213753-10 \$ 15.00 / 0$ pocampal LTP produces unstable place cells (McHugh et al., 1996; Rotenberg et al., 1996, 2000; Cho et al., 1998; Yan et al., 2002; Taverna et al., 2005). Antagonizing NMDAR transmission does not affect established place cells or remapping in a novel environment but prevents stabilization of the new place cells (Kentros et al., 1998). Furthermore, inducing LTP causes partial remapping of place cell firing fields (Dragoi et al., 2003). Thus, there is clear evidence that NMDAR-dependent LTP plays a role in place cell activity.

Recent evidence also suggests that crucial aspects of memory depend on the functional state of the atypical PKC isoform protein kinase M $\zeta$ (PKM $\zeta$ ) (Sacktor, 2011). Thus, reducing PKM $\zeta$ activity with the pseudosubstrate zeta inhibitory peptide (ZIP) or other agents erases both LTP induced by high-frequency stimulation and information acquired during experience (Pastalkova et al., 2006; Li et al., 2010; Madroñal et al., 2010; Migues et al., 2010; Sacktor, 2011). PKM $\zeta$ inhibition does not affect baseline transmission so that normal signaling is possible (Ling et al., 2002; Serrano et al., 2005; Pastalkova et al., 2006; Madroñal et al., 2010). Furthermore, this inhibition appears to erase established memories without damaging the ability to later acquire new memories (Pastalkova et al., 2006; Shema et al., 2007, 2011; Madroñal et al., 2010; Migues et al., 2010; von Kraus et al., 2010; Sacktor, 2011). Specifically, blocking hippocampal PKM $\zeta$ activity has the stated effects on synaptic activity and erases several spatial memory forms dependent on normal hippocampal function (Pastalkova et al., 2006; Serrano et al., 2008). We therefore infer that prior LTP-like synaptic plasticity within the hippocampus 
maintains organized place cell firing fields and predict that hippocampal ZIP injections should modify or abolish place cell firing fields in a familiar environment but leave intact the ability to subsequently generate new, stable fields; our goal is to test these predictions.

\section{Materials and Methods \\ Training}

The subjects were eight male Long-Evans rats $(300-350 \mathrm{~g})$ handled in accordance with the United States Public Health Service guidelines for treatment of laboratory animals. They were individually housed using a $12 \mathrm{~h}$ light/dark cycle. The first 5 training days consisted of (1) daily handling, (2) food deprivation reducing weight to $85 \%$ ad libitum, and (3) $20 \mathrm{~min} / \mathrm{d}$ of "pellet chasing" learning to forage for $25 \mathrm{mg}$ of sugar pellets scattered $\sim 2$ per minute into an arena. The arena was a white $76 \times 76 \mathrm{~cm}$ box 66 $\mathrm{cm}$ high with a $45 \mathrm{~cm}$ wide, $60 \mathrm{~cm}$ high blackand-white striped card on one wall. The box was centered in a $2.5 \times 2.5 \mathrm{~m}$ black soundproof room on a renewable piece of gray paper. Centered $2 \mathrm{~m}$ overhead was a black disk with four lights along the edge separated by $90^{\circ}$, a video camera in the middle, and a pellet feeder near the middle.

\section{Surgery}

The rat was anesthetized (Nembutal, $50 \mathrm{mg} / \mathrm{kg}$ i.p.) and placed in a stereotaxic frame. The skull was exposed and four screws inserted, two just anterior to the left and right edges of bregma, and two above left and right cerebella. Grounding was via the right cerebellum screw. Using the coordinates of Paxinos and Watson (2007), $0.8 \mathrm{~mm}$ holes were drilled at $-3.5 \mathrm{~mm}$ anteroposterior and $\pm 3.7 \mathrm{~mm}$ mediolateral above the left and right dorsal hippocampuses. These holes allowed 22 gauge injection guides to reach $1.8 \mathrm{~mm}$ dorsoventral (DV). The guides were kept patent with 30 gauge wires that reached $3.6 \mathrm{~mm} \mathrm{DV}$. A $2.6 \mathrm{~mm}$ hole $0.5 \mathrm{~mm}$ medial to the left guide hole was made for an implant, which was lowered so its tetrode tips were $2.0 \mathrm{~mm}$ below the brain surface. The skull holes were protected with sterile Vaseline. The implant was fixed via the skull screws with Grip Cement. The wound was sutured and topical antibiotic applied. The interval between surgery and cell screening was 1 week.

\section{Recordings}

Recordings were made with an eight tetrode implant (Fig. 1). Each $25 \mu \mathrm{m}$ nichrome wire was gold plated, lowering its resistance to $\sim 100 \mathrm{k} \Omega$. Tetrode signals were amplified $\times 1$ at the rat's head and led via a cable to a commutator. One tetrode was left in neocortex as a reference. Signals were bandpass filtered $300-6000 \mathrm{~Hz}$ and digitized at $30 \mathrm{kHz}$ with a 12 bit A/D converter. A spike event was stored whenever the voltage on a tetrode wire exceeded an $85-100 \mu \mathrm{V}$ threshold.

\section{Rat tracking}

Two red LEDs $3 \mathrm{~mm}$ apart were attached to the headstage. Video from the overhead camera was led to a frame grabber (DT3120, Data Translation) and digitized at $30 \mathrm{~Hz}$. Each frame was scanned for the LEDs whose locations were stored as an $\mathrm{XY}$ time series at $3.0 \times 3.0 \mathrm{~cm}$ resolution.

\section{Cell screening}

Cell-screening sessions lasted $10-45 \mathrm{~min}$. If there were $<10$ well isolated cells, inactive tetrodes were advanced $\sim 60 \mu \mathrm{m}$ and the rat spent at least $2 \mathrm{~h}$ in its cage. Once $>10$ place cells were isolated, a 16 min preinjection, baseline session was recorded. As shown below and in Results, we could identify the same cells in the preinjection session and in all postinjection sessions during the main experimental day. In some cases, we could still identify these cells on subsequent days; in others, the tetrodes had apparently moved so that waveform match- ing was not possible. In these cases, additional recordings were made on the new waveforms, without moving the tetrodes.

\section{Injections}

Three types of injections were made, two as controls and the third to test the effects of ZIP on place cell activity in a familiar environment, as a cell-level equivalent to the ability of this inhibitor of $\mathrm{PKM} \zeta$ to reverse behavioral memory. Muscimol was used to directly demonstrate that a substance with known pharmacological actions could produce predictable effects after injections near single-cell recording sites; we show in Results that muscimol has the expected effect of reducing or silencing the discharge of identified place cells. Saline injections enabled us to show that muscimol and ZIP each have major but distinct effects on place cell activity.

Muscimol. The GABA receptor agonist muscimol (5-aminomethyl3-hydroxyisoxazole; Sigma-Aldrich) was infused into the left hippocampus $(n=3)$ ipsilateral to the implant; the concentration was $0.5 \mu \mathrm{g} / \mu \mathrm{l}$ in PBS, $\mathrm{pH}$ 7.4. The injection $(1.0 \mu \mathrm{l}$ at $0.33 \mu \mathrm{l} / \mathrm{min})$ was through a 30 gauge tube in the guide. The tube was withdrawn 3 min later. After $5 \mathrm{~min}$, the rat was returned to the box for 45-60 min of recording. Recordings the next day tested for recovery from muscimol.

Saline. Tris-buffered saline, $\mathrm{pH} 7.2$, was injected (1.0 $\mu \mathrm{l}$ at $0.33 \mu \mathrm{l} /$ min) bilaterally into the dorsal hippocampuses $(n=4)$. The injections were separated by $\sim 5 \mathrm{~min}$; the first was contralateral to the tetrodes. Next, the rat was returned to its home cage for $2 \mathrm{~h}$, after which three 16 min recording sessions were done, separated by $8 \mathrm{~min}$. After 2 more hours in its cage, the rat underwent two more sessions, separated by 8 $\min$.

ZIP. Bilateral myristolated ZIP injections $(10 \mathrm{nmol} / \mu \mathrm{l}$, $\mathrm{pH} 7.2$, in Trisbuffered saline, Anaspec) were made $(n=4)$ using the same protocol as that for saline injections.

\section{Waveform clustering and stability}

Waveform clustering was done with Off-line Sorter (Plexon). The criteria used to establish clusters in the preinjection (baseline) session were applied to all subsequent sessions recorded from the same animal such that an identified single unit was recognized across multiple sessions if it appeared on the same tetrode and had the same cluster boundaries that distinguished it as a single unit. Only unitary waveforms that appeared constant across sessions were studied. The across-session stability of this waveform subset was quantified as described below. The clusters were further culled by inspecting a subset of 30 superimposed waveforms 


\begin{tabular}{|c|c|c|c|c|}
\hline Substance & Session pair & $t$ & $d f$ & Probability \\
\hline \multirow[t]{2}{*}{ Saline } & $R_{\text {Pre/P1 } 1}$ VS $S_{\text {Pre/P1 }}$ & 12.6 & 122 & $7.9 \mathrm{E}-24$ \\
\hline & $R_{\mathrm{P} 1 / \mathrm{P} 5}$ VS $S_{\mathrm{P} 1 / \mathrm{P} 55}$ & 9.4 & 120 & $4.6 \mathrm{E}-16$ \\
\hline \multirow[t]{2}{*}{ Muscimol } & $R_{\text {Pre/P1 } 1}$ VS $S_{\text {Pre/P1 }}$ & 7.1 & 80 & $4.5 \mathrm{E}-10$ \\
\hline & $R_{\mathrm{P} 1 / \mathrm{P} 5}$ VS $S_{\mathrm{P} 1 / \mathrm{P} 55}$ & 6.8 & 116 & $4.8 \mathrm{E}-10$ \\
\hline \multirow[t]{2}{*}{ ZIP } & $R_{\text {Pre/P1 } 1}$ vS $S_{\text {Pre/P1 }}$ & 7.0 & 108 & $2.3 \mathrm{E}-10$ \\
\hline & $R_{\mathrm{P} 1 / \mathrm{P} 5} \mathrm{VS} S_{\mathrm{P} 1 / \mathrm{P} 55}$ & 7.7 & 80 & $3.1 \mathrm{E}-11$ \\
\hline
\end{tabular}

randomly selected from each of the sessions recorded for a given rat. If the candidate cross-session matches were not agreed to by three independent observers, the cluster was dropped from further analysis.

We used a correlational method to show that cross-session matches made in this way are overwhelmingly better than matches between randomly paired clusters. For a given session pair, we randomly chose, for each session, $n=100$ waveforms from the putative cluster and computed $n^{2}$ Pearson product-moment correlations; the estimated waveform similarity, $S$, for this single cluster was the averaged z-transform of the $n^{2}$ values. $S$ averaged over all clusters for the session pair measures relative waveform stability. For the same session pair, we repeated this calculation, but now each cluster was matched against a different, randomly selected (without replacement) cluster yielding a second stability estimate $R$. Random selection was done by pairing only with a cluster from the same tetrode, pairing with any other cluster recorded from the same rat, and pairing with another cluster recorded from any rat. Because the results were substantially the same for each method, we report only the last one.

For each injected substance, we compared $S$ to $R$ for two key session pairs. To show that the injection did not disturb the ability to match waveforms, we used the baseline session (Pre) and the first postinjection session (P1) and compared $S_{\mathrm{Pre} / \mathrm{P} 1}$ to $R_{\mathrm{Pre} / \mathrm{P} 1}$. To show longer term waveform stability, we used P1 and the last postinjection session (P5) and compared $S_{\mathrm{P} 1 / \mathrm{P} 5}$ to $R_{\mathrm{P} 1 / \mathrm{P} 5}$. The results, summarized in Table 1, demonstrate that matching using the clustering template is much more reliable than random cluster matching.

Next, we did an ANOVA on $S_{\mathrm{Pre} / \mathrm{P} 1}$ values to determine whether waveforms are altered less by saline. For the main effect of substance, $F_{(2,157)}=$ 4.49; $p=0.013$. Tukey's post hoc tests revealed that $S_{\mathrm{Pre} / \mathrm{P} 1}$ is lower for $\operatorname{muscimol}(p=0.030)$ and ZIP $(p=0.036)$ than for saline, but muscimol and ZIP do not differ from each other $(p=0.962)$. We conclude that our correlation method is sensitive enough to detect drug-induced waveform changes compared with our estimate of variation caused by injecting vehicle. We further conclude that such drug-induced changes are insufficient to cause the profound effects of ZIP on spatial firing because similar-sized waveform effects produced by muscimol cause a totally different pattern of effects, which is properly explained by its reversible activation of $\mathrm{GABA}_{\mathrm{A}}$ receptors.

\section{Data analysis}

Recordings were from dorsal CA1. Cells were pyramidal cells or interneurons (Ranck, 1973; Fox and Ranck, 1975, 1981), but only pyramidal cells were analyzed.

The spatial resolution for analysis was $3.0 \times 3.0 \mathrm{~cm}$. Sixty-four by sixty-four firing rate arrays were constructed using standard methods (Muller et al., 1987). Rate arrays were used to (1) make colored maps to visualize positional firing distributions, (2) quantify positional distributions, and (3) compare the similarity of the firing distribution of cells in session pairs and in session halves.

In firing rate maps, the rate was zero in yellow pixels. Increasing rates are in the following order: orange, red, green, blue, and purple. Unvisited pixels are white. Positional firing distribution properties measures were based mainly on the idea of a firing field. The definition of a field is a region of $\geq 9$ contiguous pixels with firing rate $>0.1$ spikes $/ \mathrm{s}$. We calculated the overall rate, field rate, coherence, and field areas. The overall rate was the number of spikes fired by a cell divided by session time. The field rate was the number of spikes in the field divided by time in the field.
To determine coherence, we used nearest-neighbor 2-D rate autocorrelation (Muller and Kubie, 1989). Parallel lists were constructed for the firing rate in each pixel and the average in the eight nearest neighbors. Next, the product-moment correlation, $r$, between the two lists was calculated. Coherence is the z-transform of $r: z=0.5 \ln [(1+r) /(1-r)]$. Pyramidal cells with coherence $>0.3$ are taken by trained observers to be place cells. The field area was the fractional apparatus area occupied by the firing field.

A pyramidal cell was a place cell if it met the following criteria: (1) 0.1 spikes/s $<$ overall rate $<5.0$ spikes/s; field rate $>1.0$ spikes/s; (2) coherence $>0.3$; (3) field area $<0.6$ apparatus area.

We also calculated similarity. Positional firing stability was estimated from the similarity of a cell's spatial firing pattern in two time intervals. Similarity is the Fisher $\mathrm{z}$-transform of the product-moment correlation between the firing rates in corresponding pixels for two intervals. We calculated similarities between session pairs and between first and second session halves.

\section{Results}

\section{Muscimol reduces place cell firing}

To examine the predictions stated in the Introduction, we first showed that volumetric injections of aqueous solutions can be made in the near vicinity of recording tetrodes in freely moving rats without disturbing the ability to resolve individual waveforms (Hafting et al., 2008). Specifically, we found that muscimol injected ipsilateral to the tetrodes reduces or silences spiking by gating of $\mathrm{GABA}_{\mathrm{A}}$ receptors with only small changes of waveform configuration (see Materials and Methods). Implants of the design shown in Figure 1 were placed into the dorsal hippocampus of three rats so that the injection cannula was situated $3.5 \mathrm{~mm}$ below bregma. The individually movable tetrodes were gradually lowered until spikes from at least 10 well isolated CA1 pyramidal cells were observed as the rat foraged for $25 \mathrm{mg}$ of food pellets scattered into a familiar $75 \mathrm{~cm}$ square chamber. A preinjection baseline session was followed $\sim 1$ h later by injecting $1.0 \mu \mathrm{l}$ containing $4.4 \mathrm{nmol}$ of muscimol. Recordings were made soon after the injection $(\sim 10 \mathrm{~min})$ to detect the drug effect and again much later $(>10 \mathrm{~h})$ to look for recovery.

As seen in Figure 2, muscimol had the expected effect on cell activity. The properties of 8 CA1 pyramidal cells are shown in two ways for four different time intervals during the experiment. Each time interval is displayed as a row consisting of two panels, an electrical recording above that shows identified waveforms for a cell, and a firing rate map below that shows the spatial discharge distribution of the corresponding cell. In the baseline session (row 1), it is seen that each cell has a distinct waveform "signature" because of the disposition of the four tetrode wires relative to the cell. Moreover, each cell has a spatially restricted "firing field" that qualifies it as a place cell (see Materials and Methods). During the first half of the 26 min postinjection session (row 2), the place cell in the first column ceased to discharge and six of seven of the others fired much more slowly. As expected, muscimol decreased most firing rates but did not strongly alter waveforms. Interestingly, the residual firing was mainly confined to preinjection firing fields, suggesting that location-specificity does not depend entirely on the precise rate or timing of spikes. The muscimol effect was even greater during the second half of the postinjection session (row 3). Now five of eight cells were completely silent and the discharge of the remaining three was strongly reduced although waveform constancy was hardly changed. The fixed relationship between the target cells and the recording tetrodes is corroborated by the recovery session (row 4 ), when the spatial firing patterns return to their initial states after a delay of $\sim 17 \mathrm{~h}$ postinjection. 

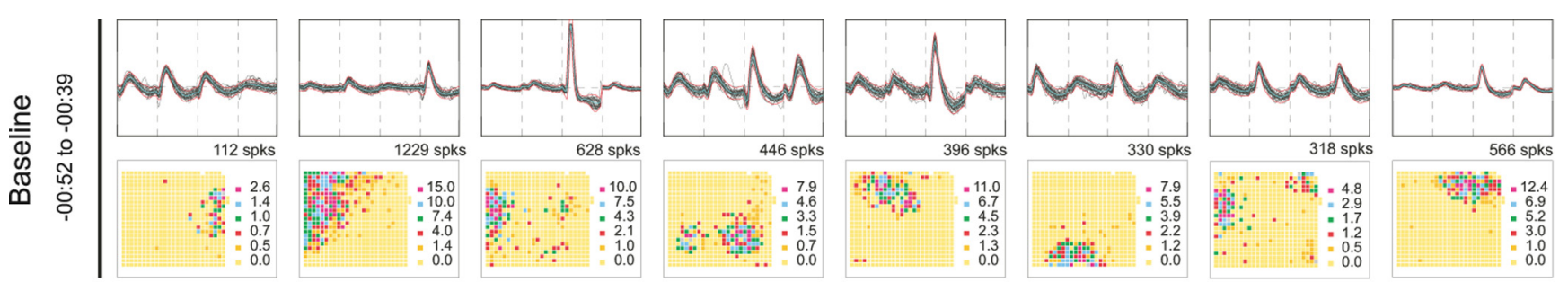

Muscimol
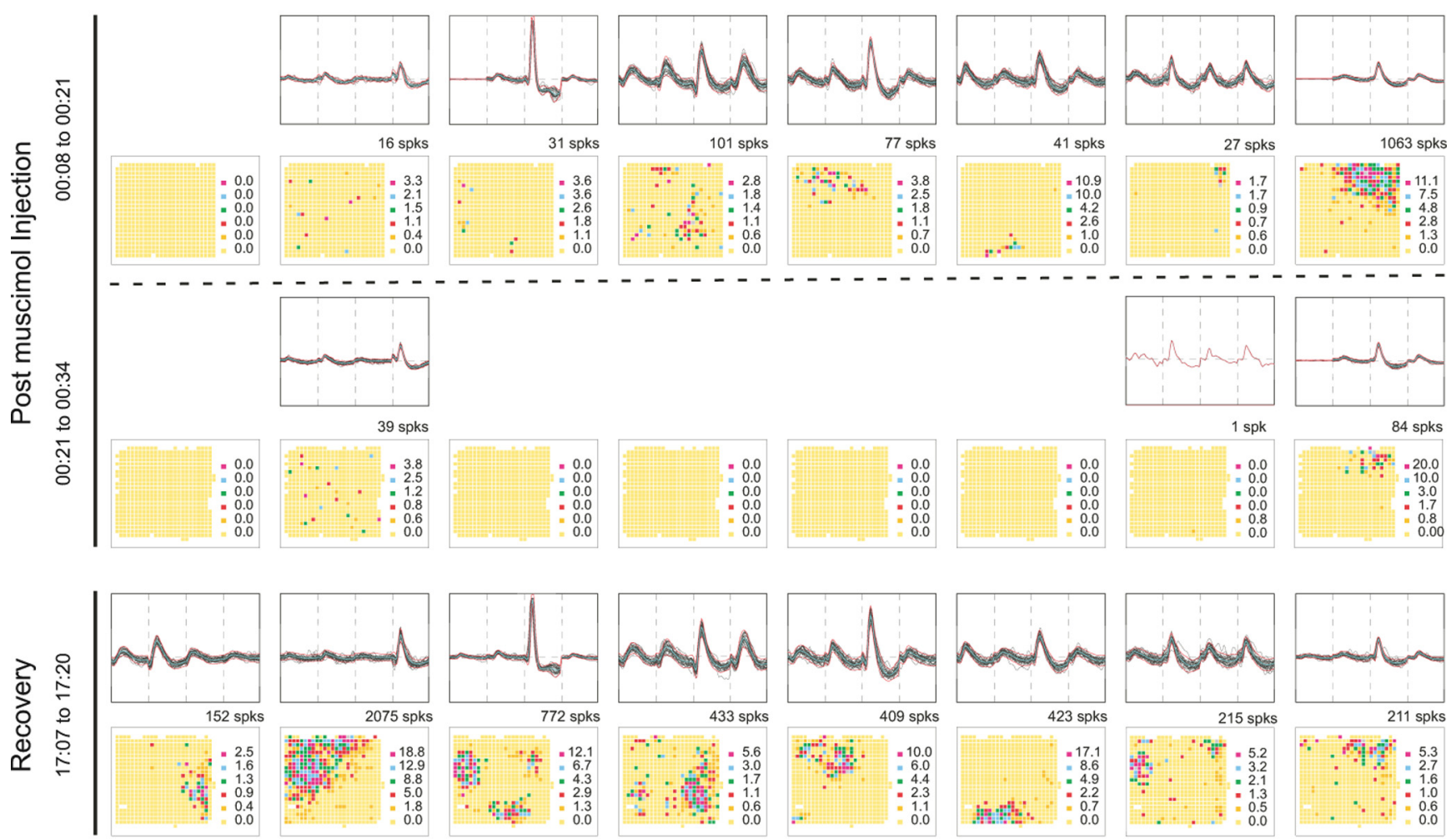

Figure 2. Muscimol reversibly inactivates place cells. Each row shows the waveform (upper half) and firing rate map (lower half) of eight simultaneously recorded place cells in a time interval. A cell's spike count is above its map. In the baseline session, each cell has a distinct waveform and a cell-specific firing field. In the initial postinjection recording interval, the first cell became silent, the next six were strongly suppressed, but the last cell fired faster. Waveforms were virtually unchanged. Residual activity is mainly confined to preinjection fields. In the second postinjection interval, five of eight cells were silent and three greatly suppressed. In a recovery session (bottom) the rate maps revert to their initial appearance.

The time course of the muscimol effect on individual place cells in an example rat is summarized in the top of Figure 3, which shows the normalized discharge rate for six cells on the "near" tetrodes and 21 cells on the "far" tetrodes. During the baseline session, the single-cell firing rates are relatively constant for each 3 min interval. In contrast, shortly after the injection, the average rate for each cell declines to nearly zero. Finally, during the late recovery session, firing returns to near its preinjection value for each tetrode. The same picture emerges when averages are taken for the near and far tetrodes (Fig. 3, bottom), but in the postinjection session the silencing of cells on the far tetrodes is delayed by $\sim 360 \mathrm{~s}$. If the delay time $t=360 \mathrm{~s}$ and the diffusion distance (between the tetrode rows) $x=0.5 \mathrm{~mm}$, we can find the apparent diffusion constant $D$ using the Einstein diffusion equation $D=$ $x^{2} / 2 t$. We estimate $D=3.5 \times 10^{-6} \mathrm{~cm}^{2} \mathrm{~s}^{-1}$ in a biological tissue, a reasonable value for a molecule of $\mathrm{MW}=114.1$ compared with the value of $1.6 \times 10^{-6} \mathrm{~cm}^{2} \mathrm{~s}^{-1}$ for glucose $(\mathrm{MW}=180.2)$ in sclera or dura (Bashkatov et al., 2003a,b).

Similar results in two other muscimol experiments lead us to conclude that stable recordings are possible after injections close to recording probes. The results from the recovery session also suggest that the form of memory necessary to maintain stable firing fields after $>3$ weeks of familiarity with the environment does not depend on continued spiking, even if the animal is exposed to the environment during the activity reduction.

\section{Firing fields are stable after saline}

Having found that muscimol injections affect discharge rate with hardly any modification of waveforms, we next asked whether vehicle injections alter any aspect of place cell discharge. Tetrode waveforms and spatial firing distributions of eight CA1 place cells are shown for a baseline session preceding bilateral injection of $1.0 \mu \mathrm{l}$ of buffered saline, pH 7.2 (Fig. 4, top row). A second session $2 \mathrm{~h}$ after the saline injection (Fig. 4, row 2) demonstrates both waveform and firing field stability. The similarity (pixel-bypixel correlation) of the firing pattern in the $2 \mathrm{~h}$ postinjection session relative to the baseline session is given below each map; in each case, the probability that similarity equals 0 is $\ll 0.0001$.

As expected (Muller et al., 1987), rate maps for additional postsaline sessions (Fig. 3, rows 3-6) reveal longer-term firing field stability. The plot in Figure 6 of mean similarity between the baseline session and each postsaline session demonstrates long- 

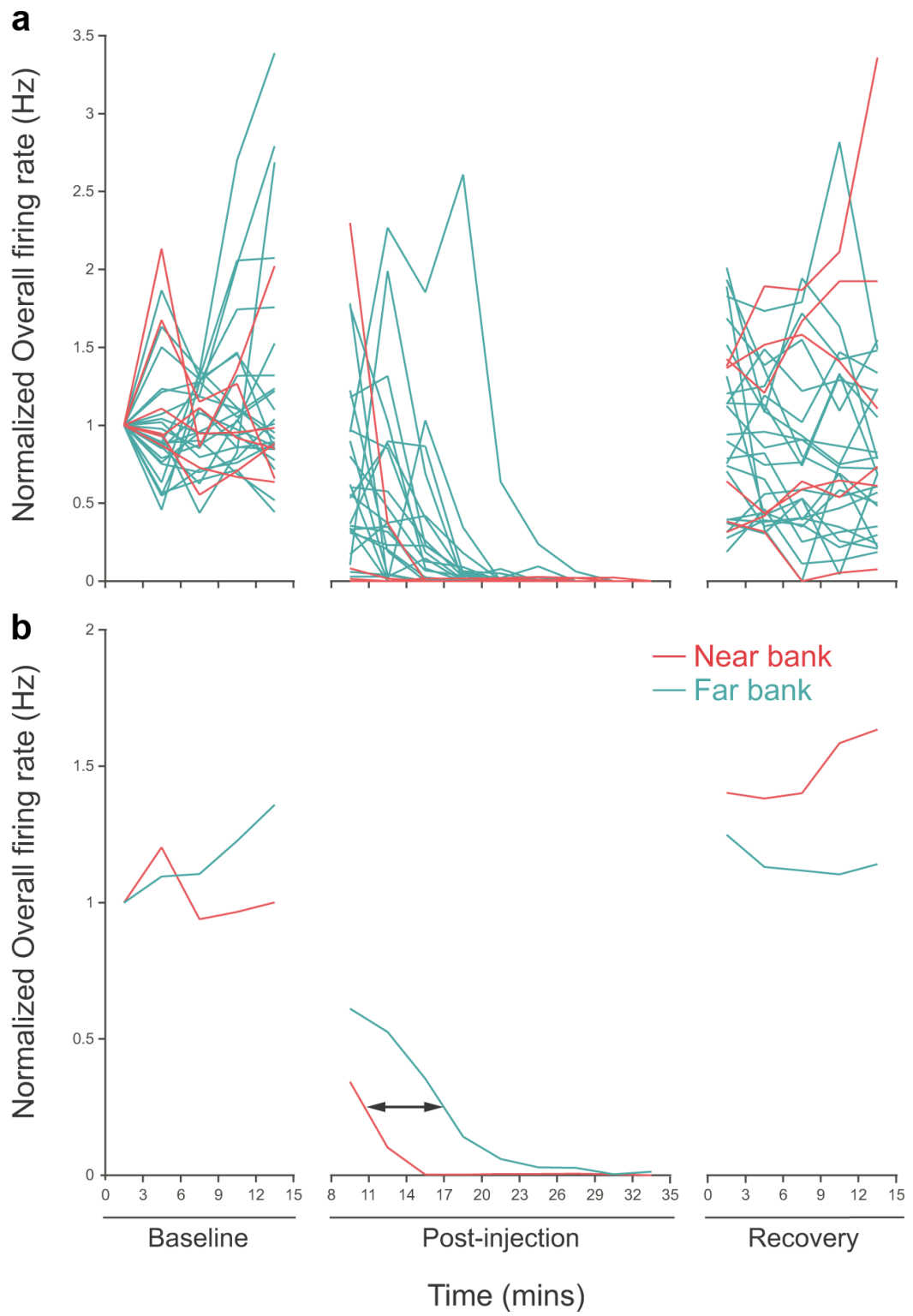

Figure 3. Timing of muscimol action on near-bank and far-bank tetrodes. $\boldsymbol{a}$, Normalized overall rate during the baseline, postinjection, and recovery intervals for six near-bank cells (red) and 21 far-bank cells (green). At beginning of the postinjection interval, the discharge of most cells on near-bank tetrodes is suppressed, whereas there is a noticeable delay for cells on far-bank tetrodes. The last interval shows recovery for cells on both near and far tetrode banks. $\boldsymbol{b}$, Normalized firing rate averaged for cells on near-bank and far-bank tetrodes for the three intervals. The average rates are quite constant in the baseline and recovery intervals. After the injection, the delayed muscimol effect for cells recorded from far-bank tetrodes appears as a rightward shift of $\sim 6.0 \mathrm{~min}$.

term stability for 62 place cells from four rats. Thus, after volumetric administration of an inactive solution, place cells in a fixed environment exhibit the same constancy of spatial discharge as they do in repeated recordings with no intervening treatment (Muller et al., 1987).

\section{ZIP destabilizes location-specific firing}

The positive and negative control experiments with muscimol and saline provide a sufficient basis for determining if ZIP injections disturb place cell discharge in a familiar environment. The top row of Figure 5 shows waveforms and firing rate maps for eight CA1 place cells recorded during a baseline session before bilaterally injecting $1.0 \mu \mathrm{l}$ containing $10 \mathrm{nmol}$ ZIP. A postinjection session done $2 \mathrm{~h}$ later (row 2 ) reveals major changes in spatial

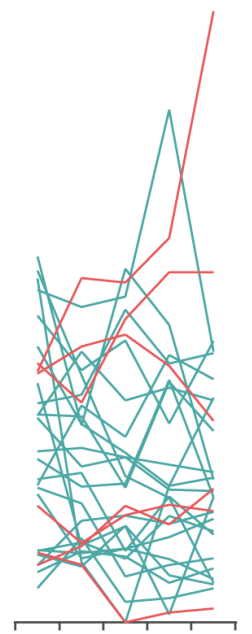

firing patterns. By inspection of the maps, these include dispersion of discharge (cells 1 and 5), clear decreases in firing rate (cells 3 and 8), and strong alterations in firing fields (cells 2, 4, 6, and 7). Thus, the characteristic reproducibility of place cell firing fields in a familiar environment is absent. The instability visible by comparing the baseline and $2 \mathrm{~h}$ post-ZIP sessions is corroborated by the very low similarity below each $2 \mathrm{~h}$ map, which can be contrasted with the much higher values after saline injections (Fig. 4). After Bonferroni correction to $\alpha=$ 0.00625 , there is a significant positive correlation only for cell 3 .

Rate maps for the example cells from later sessions suggest that field reorganization can occur several times in the hours after ZIP injection (Fig. 5, rows 3-6). Nevertheless, when the similarity between the baseline session and each post-ZIP session is plotted (Fig. $6 a$ ), the low average values indicate that spatial firing distributions ( 83 place cells from 4 rats) never revert to their pre-ZIP patterns. An ANOVA of similarity to the baseline with injection substance as the primary variable and session as a repeated measure shows a main effect $\left(F_{(1,6)}=26.19 ; p=0.0022\right)$, a session effect $\left(F_{(4,24)}=4.01 ; p=0.012\right)$, but no interaction $\left(F_{(4,24)}=2.21 ; p=0.098\right)$.

We next asked whether the destabilization of spatial firing patterns occurs preferentially for those place cell clusters whose waveforms were noisier or harder to separate from other clusters. In this analysis, we computed two measures of cluster isolation quality (Neymotin et al., 2011), namely, isolation from the background ( $\mathrm{Isol}_{\mathrm{BG}}$ ) and isolation from the nearest neighbor cluster $\left(\mathrm{Isol}_{\mathrm{NN}}\right)$. We found that the correlation between each of these measures and the similarity of the baseline (Pre) and first postinjection $(\mathrm{P} 1)$ sessions $\left(S_{\text {pre/P1 }}\right)$ were not significant $\left[r\left(\mathrm{Isol}_{\mathrm{BG}} / S\right)=-0.114 ; p=\right.$ 0.31. $\left.r\left(\mathrm{Isol}_{\mathrm{NN}} / S\right)=-0.209 ; p=0.06\right]$. Thus, there is no tendency for disruption to occur more frequently for lower-quality clusters.

\section{New firing fields can stabilize after ZIP injections}

Plotting the similarity between pairs of successive sessions suggests that firing fields may stabilize $\sim 5 \mathrm{~h}$ after injecting ZIP (Fig. $6 b)$. This impression is reinforced by a $t$ test showing that the mean similarity between post-ZIP sessions 5 and 6 is higher than between sessions 4 and $5\left(t_{6}=2.95 ; p=0.026\right)$. There is no such increase in mean similarity after saline injections $\left(t_{6}=1.30 ; p=\right.$ 0.245). A two-way repeated measure ANOVA with injection as one factor and session pairs $4 / 5$ versus $5 / 6$ as the other also indicates a trend toward a significant injection-session pair interac- 


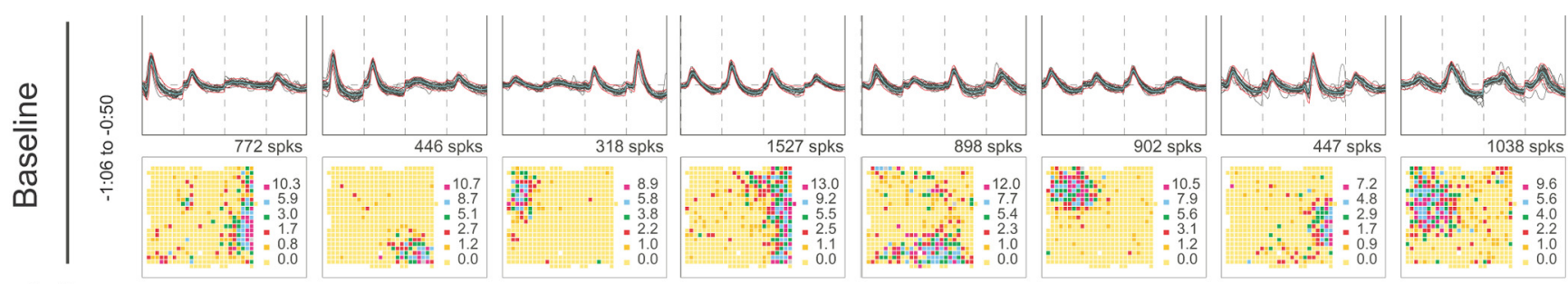

Saline
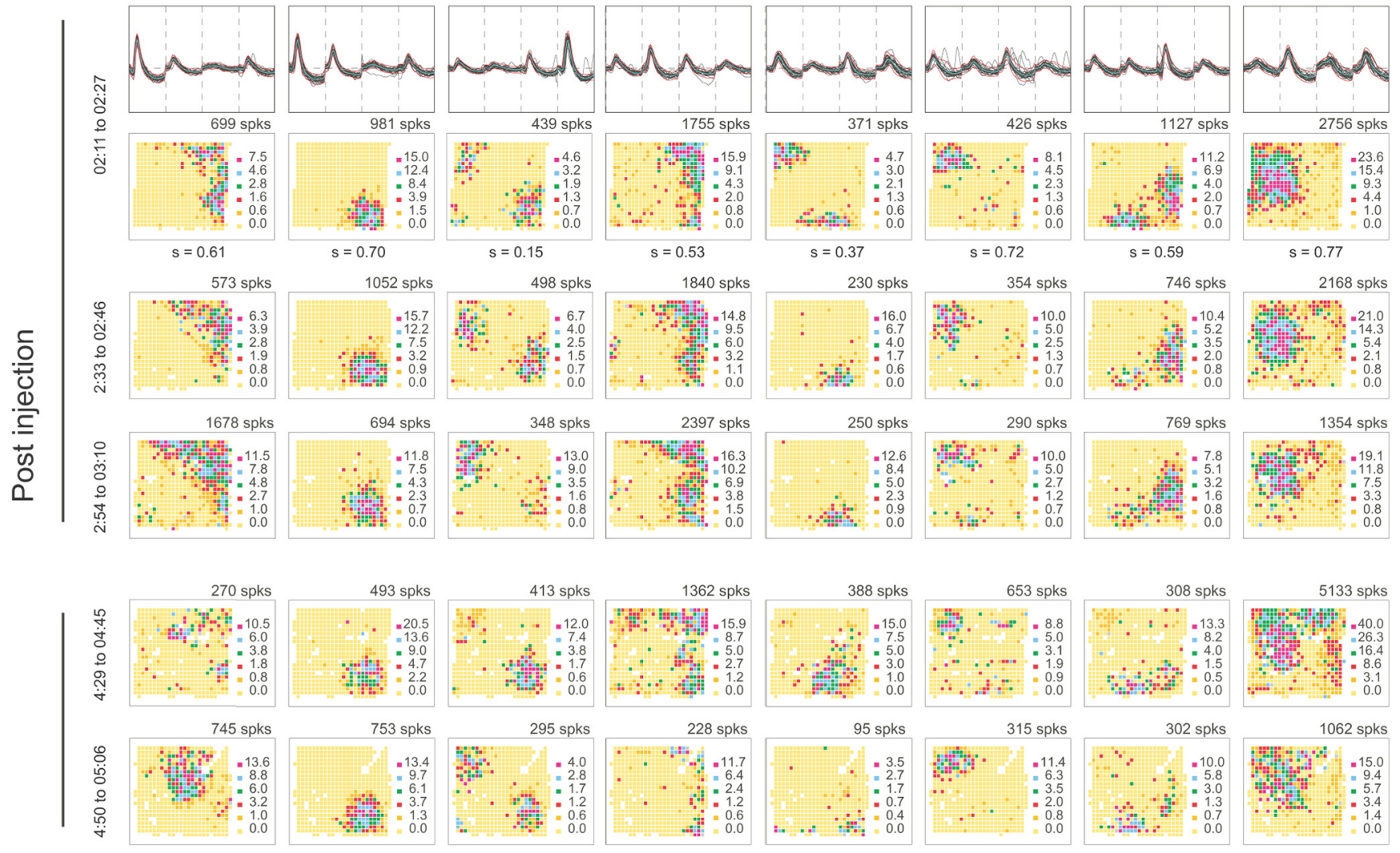

Figure 4. Place cell firing is unchanged by saline injections. The activity of eight simultaneously recorded cells before and after injecting $1.0 \mu$ l of saline ipsilateral to the tetrodes is shown. The baseline session row (top) and initial postinjection session (second) row show waveforms and rate maps; only rate maps are shown in later rows. A cell's spike count is above its firing rate map; the similarity of the first postinjection session to the baseline session is below each map. The high similarities indicate preservation of spatial firing patterns after the saline injection.

tion $(F=3.11 ; p=0.11)$, as if the session pair similarity improved more for ZIP than saline rats.

Because we did not successfully hold waveforms into the next day after ZIP injections for any ZIP rat, we do not know whether the new spatial firing patterns in sessions 5 and 6 would have persisted. Importantly, however, in recordings made on days after the ZIP injection, firing fields were stable for session pairs recorded in three of three rats; no cells were found on later days for the last rat. In one rat, the mean similarity for two sessions separated by a $20 \mathrm{~min}$ interval was $0.62(n$ cells $=22)$. In the same rat, the mean similarity was $0.43(n=14)$ for two sessions separated by $20 \mathrm{~h}$ on the second and third days after the ZIP injection. In a second rat, the mean similarity was $0.48(n=11)$ for a $20 \mathrm{~min}$ session interval and $0.43(n=7)$ for a $3 \mathrm{~h}$ interval on post-ZIP day 4. In the third rat, the mean similarity was $0.54(n=10)$ with an intersession interval of $20 \mathrm{~min}$. For each of the three rats, the mean similarity was reliably higher between the two delayed sessions than between the pre-ZIP session and the first post-ZIP session. Along with the elevated firing field similarity between sessions 5 and 6 on the ZIP injection day, these additional record- ings suggest that the ZIP effect is transient so that, with the passage of time, it is possible for a new map to form.

\section{Fields are destabilized within sessions}

Although ZIP injections render place cells unstable across sessions, individual cells might become tuned to selected stimulus features for the duration of each session, accounting for the confinement of discharge to portions of the cylinder rather than noisy firing everywhere. We tested this by calculating the similarity between spatial discharge in the first half and the second half of each postinjection session (Fig. 6c). An ANOVA of half-session similarity with session as a repeated measure and injection as the primary variable shows a main effect $\left(F_{(1,6)}=24.26 ; p=0.0026\right)$, no effect of session $\left(F_{(4,24)}=4.01 ; p=0.79\right)$, but an injection by session interaction $\left(F_{(4,24)}=7.01 ; p=0.0007\right)$. With Bonferroni correction to $\alpha=0.01, t$ tests indicate the half-session similarity after ZIP injections is significantly lower than after saline injections for sessions 2, 3, and 4, but not for sessions 5 and 6 . Thus, the availability of fixed stimuli does not induce within-session stability for relatively short times after the ZIP injection. Never- 

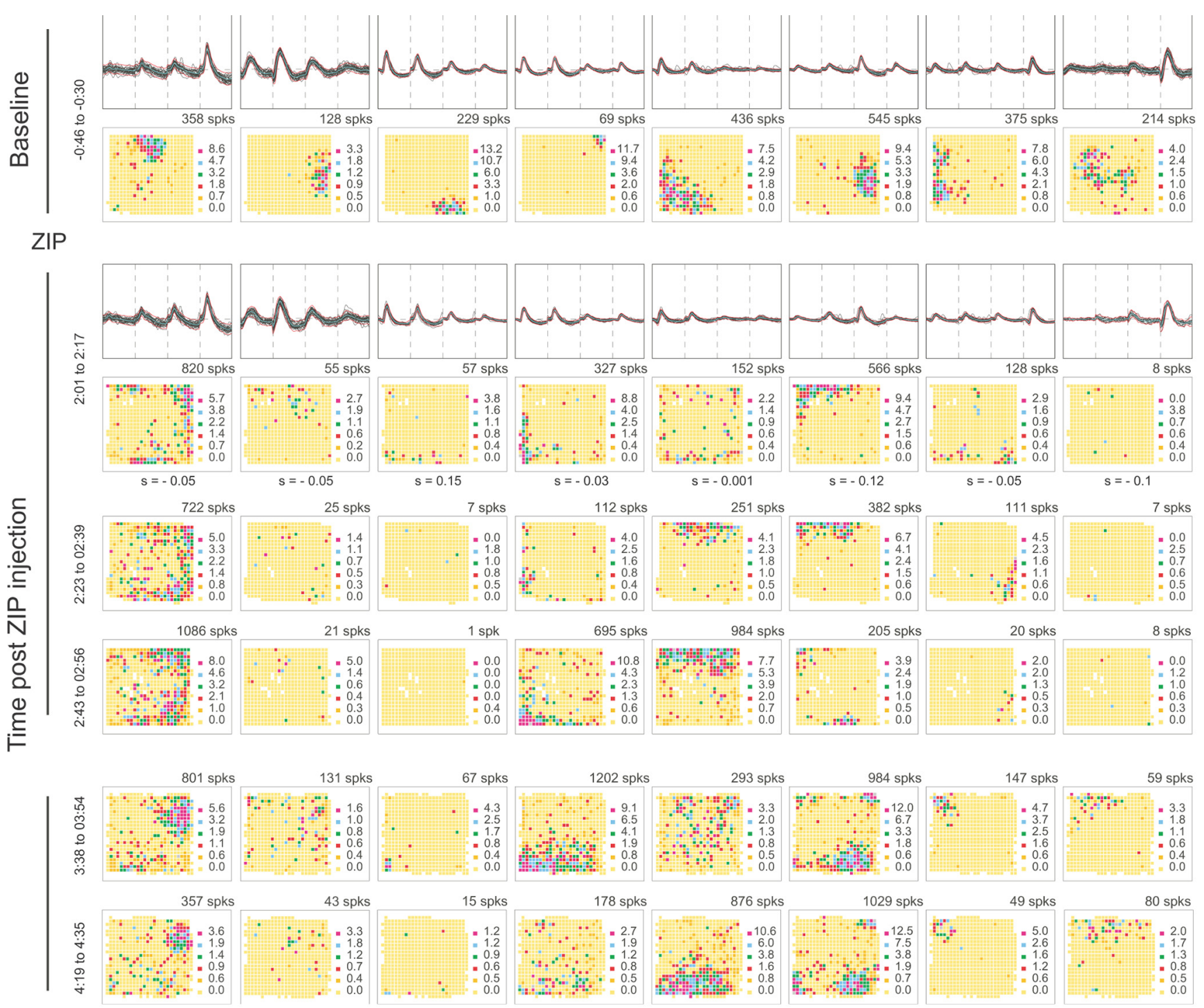

Figure 5. ZIP injections disrupt place cells. The activity of eight simultaneously recorded cells before and after bilateral injections of $1.0 \mu$ I ZIP. The baseline (top) row and initial postinjection (second) row show each cell's waveform and rate map; only rate maps are shown in later rows. Spike counts are above each map. The similarity (s) of the first postinjection session to the baseline session is below each map. The low similarities indicate that the spatial firing patterns have been drastically modified by the ZIP injection. Spatial firing patterns show little constancy between consecutive sessions except for the last pair (rows 5 and 6 ).

theless, at longer times, within-session stability tends to increase in parallel with between-session stability.

\section{Discussion}

To ask how blocking PKM $\zeta$ activity affects place cells, we designed and used an implant to inject aqueous solutions $\sim 1.5-2.0 \mathrm{~mm}$ from tetrodes in the CA1 pyramidal cell layer. We first saw that injecting the $\mathrm{GABA}_{\mathrm{A}}$ agonist muscimol gradually reduced neuronal spiking activity without strongly altering waveforms or the spatial location of residual activity. We also showed that the muscimol effect delay between the near and far tetrodes could be ascribed to diffusion of a species with the molecular weight of muscimol. The recovery of firing rate in unchanged firing fields $\sim 20 \mathrm{~h}$ after muscimol injection also implies the method is sound, as do the near invariance of waveform and location-specific firing after saline injections. Interestingly, waveform shape, while largely preserved after all three injection types, was detectably more altered by muscimol and ZIP than saline, which is as expected if muscimol and ZIP (but not saline) affect synaptic conductances and, therefore, extracellular current flow during spikes.

Although we did not test spatial performance in this study, our central finding is that bilateral hippocampal ZIP injections profoundly alter the location-specific firing of CA1 place cells, providing an account of why similar injections erase hippocampal-dependent spatial memory. In this view, the ZIP-induced reorganization of spatial firing patterns explain the rat's inability to avoid a specific region of space, to efficiently go to a hidden goal in the Morris swimming task, or to visit only baited arms of a radial maze (Pastalkova et al., 2006; Serrano et al., 2008). The irreversible memory loss has a parallel with the persistently reduced similarity between the pre-ZIP and post-ZIP spatial firing patterns; the original firing field set does not return. Based on cognitive map theory (O'Keefe and Nadel, 1978), we argue that such memory losses occur not because the rat has forgotten the task itself, but because of disruptions of map-like representations of familiar environments maintained by the rat's 
hippocampal place cells; the rat cannot accurately use environmental features because it is lost in effectively unexplored space (Pastalkova et al., 2006; Serrano et al., 2008). Note, however, that rules for the task performance may have been disrupted. Also, we have to consider that, while the map appears to have been erased, it may still exist in a latent form that can no longer be retrieved.

A hallmark of memory deficits following ZIP injections is that the rat can be retrained in the same task; performance is lost because the memory is erased and not because the storage mechanism is irreversibly damaged (Pastalkova et al., 2006; Shema et al., 2007). In parallel with this key observation, we see that new firing fields for some continuously recorded pyramidal cells begin to stabilize with the passage of sufficient time after ZIP injection. Specifically, similarity values for place cells in session pairs beginning $5 \mathrm{~h}$ after ZIP injections approach the levels seen after saline injections; within-session stability also improves around the same time. In addition, when new sets of waveforms are recorded long after a ZIP injection, their spatial firing patterns are stable between sessions, as expected if the storage machinery is intact. Thus, the ability of rats to relearn a spatial task after ZIP erasure does not require transfer of function to alternative neural machinery. Instead, the rats use the very same network components originally involved.

The observed formation of new, stable firing fields $5 \mathrm{~h}$ after injection provides an estimate of the duration of action of ZIP. If future place cell recordings reveal that fields present at $5 \mathrm{~h}$ remain stable overnight, the prediction is that retraining in a behavioral task will be effective after $5 \mathrm{~h}$.

Our data are inconsistent with the idea that place cell activity is triggered by a fixed set of converging input cells with constant synaptic input strengths, including grid cells (Fyhn et al., 2004; Hafting et al., 2005), ventral medial entorhinal place-like cells (Quirk et al., 1992), or some unknown cell type, as is proposed by several theories (McNaughton et al., 2006; Solstad et al., 2006). If such feed-forward models were correct, the spatial firing pattern of each cell would return to its original state after any transient disruption caused by ZIP. We find, however, that the new pattern is as different from the original as that formed after remapping. This suggests that the spatial firing patterns of place cells are instead constructed from a process in which place cell activity is fed back to the entorhinal cells. Our observations also suggest that place cell firing fields may also arise from a random combination of inputs selected by an activity-dependent process, likely an endogenous LTP-like synaptic plasticity maintained by PKM $\zeta$ activity (Pastalkova et al., 2006; Sacktor, 2011).

If the reorganization of firing fields after ZIP injections are as complete as after remapping (Muller and Kubie, 1987; Lever et al., 2002), how do the two phenomena differ? We suggest there are two essential distinctions. First, ZIP induces firing pattern changes in a constant, familiar environment, whereas remapping occurs when the surroundings are sufficiently modified. Remapping, or at least partial remapping, can occur in a familiar environment, but this requires prolonged exposure (Bostock et al., 1991; Lever et al., 2002), changes in the task (Markus et al., 1995), or changes of behavioral contingencies (Moita et al., 2004). In our opinion, ZIP-induced reorganizations most closely resemble the spontaneous remappings reported in mice without reinforcement to explore their environment (Kentros et al., 2004) and in senescent rats paralleled by transient performance deficits (Barnes et al., 1997). The ZIP effect differs from these observations as well as other multistable map-switching phenomena that have been observed (Kelemen and Fenton, 2010) and is predicted by models in which the hippocampus can toggle between transiently stable map-like collections of place cell firing patterns (for review, see Redish, 1999; Touretzky and Muller, 2006). The key difference is that after ZIP the firing fields do not jump from one stable across-cell state to another but instead continuously drift across and within post-ZIP sessions 1-5.

A second difference between ZIP effects and remapping is the characteristic time course of subsequent stabilization; in remapping between a familiar and a novel environment, the new firing patterns are stable after a single exposure to the novel environment (Kentros et al., 1998), whereas it takes hours for place cell activity to become constant after ZIP. It is interesting that blockade of NMDA receptors during the initial exposure to the novel environment does not interfere with remapping nor with shortterm (1-2 h) stability (Kentros et al., 1998; Ekstrom et al., 2001). The implication is that the immediate firing pattern changes that occur during NMDAR antagonism are supported by an alternative form of plasticity. Thus, NMDAR-based plasticity is required for stabilization (consolidation) of firing fields but not their initial formation. On the other hand, as our results suggest, once fields are stabilized by NMDAR-initiated processes, they are vulnerable to interference with the AMPA receptor-based machinery that maintains the plastic modifications (Sacktor, 2011).

The consequences of ZIP injections may also be differentiated from "overdispersion," another form of firing field instability in which place cells discharge much more rapidly or slowly than expected from their time-averaged rates on individual passes of the rat through fields (Fenton and Muller, 1998; Olypher et al., 2002). The instability of overdispersion occurs on an attentionlike timescale of $\sim 1 \mathrm{~s}$ and is associated with normal field stability within a recording session and between sessions (Jackson and Redish, 2007; Fenton et al., 2010). In contrast, ZIP injections decreased field stability between the first and second halves of early sessions and between successive early sessions. Indeed, the ZIP-induced instability precludes the overdispersion calculations for measuring the firing variability on individual passes of the rat through a firing field because the calculations assume withinsession field stability (Fenton and Muller, 1998). 
The lack of within-session stability after ZIP is interesting because it suggests that the stimuli to which place cells are tuned fluctuate at a relatively rapid rate, on the order of minutes. Because tetanus-induced, $\mathrm{PKM} \zeta$-mediated LTP maintenance is initiated by NMDA receptor activation (Sacktor, 2011), at first glance these ZIP-induced, within-session firing field fluctuations seem to contradict the idea of a non-NMDAR-based plasticity mechanism that accounts for normal field formation and the 1-2 h-long interval of stability during NMDA receptor blockade (Kentros et al., 1998). We speculate, however, that an essential consequence of either NMDAR or non-NMDAR synaptic potentiation is insertion by $\mathrm{PKM} \zeta$ of additional AMPA receptors at appropriate postsynaptic sites. We argue, in other words, that ZIP injections reveal a final common pathway for synaptic modification at CA1 and likely other contacts in the hippocampal formation. At the same time, however, it seems there is always a form of short time-scale tuning because the temporal variations do not lead to noisy, environment-wide discharge. It is as if the process of place cell formation is always being initiated but cannot go to completion; incipient firing fields may decay almost as quickly as they coalesce.

\section{References}

Barnes CA, Suster MS, Shen J, McNaughton BL (1997) Multistability of cognitive maps in the hippocampus of old rats. Nature 388:272-275. CrossRef Medline

Bashkatov AN, Genina EA, Sinichkin IuP, Kochubeř VI, Lakodina NA, Tuchin VV (2003a) Determination of glucose diffusion coefficient in the human eye sclera (in Russian). Biofizika 48:309-313. Medline

Bashkatov AN, Genina EA, Sinichkin YP, Kochubey VI, Lakodina NA, Tuchin VV (2003b) Glucose and mannitol diffusion in human dura mater. Biophys J 85:3310-3318. CrossRef Medline

Bostock E, Muller RU, Kubie JL (1991) Experience-dependent modifications of hippocampal place cell firing. Hippocampus 1:193-205. CrossRef Medline

Cho YH, Giese KP, Tanila H, Silva AJ, Eichenbaum H (1998) Abnormal hippocampal spatial representations in alphaCaMKIIT286A and CREBalphaDelta- mice. Science 279:867-869. CrossRef Medline

Dragoi G, Harris KD, Buzsáki G (2003) Place representation within hippocampal networks is modified by long-term potentiation. Neuron 39: 843-853. CrossRef Medline

Ekstrom AD, Meltzer J, McNaughton BL, Barnes CA (2001) NMDA receptor antagonism blocks experience-dependent expansion of hippocampal "place fields". Neuron 31:631-638. CrossRef Medline

Fenton AA, Muller RU (1998) Place cell discharge is extremely variable during individual passes of the rat through the firing field. Proc Natl Acad Sci U S A 95:3182-3187. CrossRef Medline

Fenton AA, Lytton WW, Barry JM, Lenck-Santini PP, Zinyuk LE, Kubík S, Bures J, Poucet B, Muller RU, Olypher AV (2010) Attention-like modulation of hippocampus place cell discharge. J Neurosci 30:4613-4625. CrossRef Medline

Fox SE, Ranck JB Jr (1975) Localization and anatomical identification of theta and complex spike cells in dorsal hippocampal formation of rats. Exp Neurol 49:299-313. CrossRef Medline

Fox SE, Ranck JB Jr (1981) Electrophysiological characteristics of hippocampal complex-spike cells and theta cells. Exp Brain Res 41:399-410. Medline

Fyhn M, Molden S, Witter MP, Moser EI, Moser MB (2004) Spatial representation in the entorhinal cortex. Science 305:1258-1264. CrossRef Medline

Hafting T, Fyhn M, Molden S, Moser MB, Moser EI (2005) Microstructure of a spatial map in the entorhinal cortex. Nature 436:801-806. CrossRef Medline

Hafting T, Fyhn M, Bonnevie T, Moser MB, Moser EI (2008) Hippocampus-independent phase precession in entorhinal grid cells. Nature 453:1248-1252. CrossRef Medline

Jackson J, Redish AD (2007) Network dynamics of hippocampal cellassemblies resemble multiple spatial maps within single tasks. Hippocampus 17:1209-1229. CrossRef Medline
Kelemen E, Fenton AA (2010) Dynamic grouping of hippocampal neural activity during cognitive control of two spatial frames. PLoS Biol 8:e1000403. CrossRef Medline

Kentros CG, Agnihotri NT, Streater S, Hawkins RD, Kandel ER (2004) Increased attention to spatial context increases both place field stability and spatial memory. Neuron 42:283-295. CrossRef Medline

Kentros C, Hargreaves E, Hawkins RD, Kandel ER, Shapiro M, Muller RV (1998) Abolition of long-term stability of new hippocampal place cell maps by NMDA receptor blockade. Science 280:2121-2126. CrossRef Medline

Lever C, Wills T, Cacucci F, Burgess N, O’Keefe J (2002) Long-term plasticity in hippocampal place-cell representation of environmental geometry. Nature 416:90-94. CrossRef Medline

Li XY, Ko HG, Chen T, Descalzi G, Koga K, Wang H, Kim SS, Shang Y, Kwak C, Park SW, Shim J, Lee K, Collingridge GL, Kaang BK, Zhuo M (2010) Alleviating neuropathic pain hypersensitivity by inhibiting PKMzeta in the anterior cingulate cortex. Science 330:1400-1404. CrossRef Medline

Ling DS, Benardo LS, Serrano PA, Blace N, Kelly MT, Crary JF, Sacktor TC (2002) Protein kinase Mzeta is necessary and sufficient for LTP maintenance. Nat Neurosci 5:295-296. CrossRef Medline

Liu X, Muller RU, Huang LT, Kubie JL, Rotenberg A, Rivard B, Cilio MR, Holmes GL (2003) Seizure-induced changes in place cell physiology: relationship to spatial memory. J Neurosci 23:11505-11515. Medline

Madroñal N, Gruart A, Sacktor TC, Delgado-García JM (2010) PKMzeta inhibition reverses learning-induced increases in hippocampal synaptic strength and memory during trace eyeblink conditioning. PLoS One 5:e10400. CrossRef Medline

Markus EJ, Qin YL, Leonard B, Skaggs WE, McNaughton BL, Barnes CA (1995) Interactions between location and task affect the spatial and directional firing of hippocampal neurons. J Neurosci 15:7079-7094. Medline

McHugh TJ, Blum KI, Tsien JZ, Tonegawa S, Wilson MA (1996) Impaired hippocampal representation of space in CA1-specific NMDAR1 knockout mice. Cell 87:1339-1349. CrossRef Medline

McNaughton BL, Battaglia FP, Jensen O, Moser EI, Moser MB (2006) Path integration and the neural basis of the "cognitive map". Nat Rev Neurosci 7:663-678. CrossRef Medline

Migues PV, Hardt O, Wu DC, Gamache K, Sacktor TC, Wang YT, Nader K (2010) PKMzeta maintains memories by regulating GluR2-dependent AMPA receptor trafficking. Nat Neurosci 13:630-634. CrossRef Medline

Moita MA, Rosis S, Zhou Y, LeDoux JE, Blair HT (2004) Putting fear in its place: remapping of hippocampal place cells during fear conditioning. J Neurosci 24:7015-7023. CrossRef Medline

Muller RU, Kubie JL (1987) The effects of changes in the environment on the spatial firing of hippocampal complex-spike cells. J Neurosci 7:19511968. Medline

Muller RU, Kubie JL (1989) The firing of hippocampal place cells predicts the future position of freely moving rats. J Neurosci 9:4101-4110. Medline

Muller RU, Kubie JL, Ranck JB Jr (1987) Spatial firing patterns of hippocampal complex-spike cells in a fixed environment. J Neurosci 7:19351950. Medline

Nakazawa K, McHugh TJ, Wilson MA, Tonegawa S (2004) NMDA receptors, place cells and hippocampal spatial memory. Nat Rev Neurosci 5:361-372. CrossRef Medline

Neymotin SA, Lytton WW, Olypher AV, Fenton AA (2011) Measuring the quality of neuronal identification in ensemble recordings. J Neurosci 31: 16398-16409. CrossRef Medline

O'Keefe J, Nadel L (1978) The hippocampus as a cognitive map. Oxford: Clarendon.

Olypher AV, Lánský P, Fenton AA (2002) Properties of the extra-positional signal in hippocampal place cell discharge derived from the overdispersion in location-specific firing. Neuroscience 111:553-566. CrossRef Medline

Pastalkova E, Serrano P, Pinkhasova D, Wallace E, Fenton AA, Sacktor TC (2006) Storage of spatial information by the maintenance mechanism of LTP. Science 313:1141-1144. CrossRef Medline

Paxinos G, Watson C (2007) The rat brain in stereotaxic coordinates, 6th edition. Amsterdam: Academic/Elsevier.

Quirk GJ, Muller RU, Kubie JL, Ranck JB Jr (1992) The positional firing properties of medial entorhinal neurons: description and comparison with hippocampal place cells. J Neurosci 12:1945-1963. Medline 
Ranck JB Jr (1973) Studies on single neurons in dorsal hippocampal formation and septum in unrestrained rats. I. Behavioral correlates and firing repertoires. Exp Neurol 41:461-531. Medline

Redish AD (1999) Beyond the cognitive map: from place cells to episodic memory. Cambridge, MA: MIT.

Rotenberg A, Mayford M, Hawkins RD, Kandel ER, Muller RU (1996) Mice expressing activated CaMKII lack low frequency LTP and do not form stable place cells in the CA1 region of the hippocampus. Cell 87:13511361. CrossRef Medline

Rotenberg A, Abel T, Hawkins RD, Kandel ER, Muller RU (2000) Parallel instabilities of long-term potentiation, place cells, and learning caused by decreased protein kinase A activity. J Neurosci 20:8096-8102. Medline

Sacktor TC (2011) How does PKMzeta maintain long-term memory? Nat Rev Neurosci 12:9-15. CrossRef Medline

Serrano P, Yao Y, Sacktor TC (2005) Persistent phosphorylation by protein kinase Mzeta maintains late-phase long-term potentiation. J Neurosci 25:1979-1984. CrossRef Medline

Serrano P, Friedman EL, Kenney J, Taubenfeld SM, Zimmerman JM, Hanna J, Alberini C, Kelley AE, Maren S, Rudy JW, Yin JC, Sacktor TC, Fenton AA (2008) PKMzeta maintains spatial, instrumental, and classically conditioned long-term memories. PLoS Biol 6:2698-2706. CrossRef Medline
Shema R, Sacktor TC, Dudai Y (2007) Rapid erasure of long-term memory associations in the cortex by an inhibitor of PKM zeta. Science 317:951953. CrossRef Medline

Shema R, Haramati S, Ron S, Hazvi S, Chen A, Sacktor TC, Dudai Y (2011) Enhancement of consolidated long-term memory by overexpression of protein kinase Mzeta in the neocortex. Science 331:1207-1210. CrossRef Medline

Solstad T, Moser EI, Einevoll GT (2006) From grid cells to place cells: a mathematical model. Hippocampus 16:1026-1031. CrossRef Medline

Taverna FA, Georgiou J, McDonald RJ, Hong NS, Kraev A, Salter MW, Takeshima H, Muller RU, Roder JC (2005) Defective place cell activity in nociceptin receptor knockout mice with elevated NMDA receptordependent long-term potentiation. J Physiol 565:579-591. CrossRef Medline

Touretzky D, Muller RU (2006) Place field dissociation and multiple maps in hippocampus. Neurocomputing 69:1260-1263. CrossRef

von Kraus LM, Sacktor TC, Francis JT (2010) Erasing sensorimotor memories via PKMzeta inhibition. PLoS One 5:e11125. CrossRef Medline

Yan J, Zhang Y, Jia Z, Taverna FA, McDonald RJ, Muller RU, Roder JC (2002) Place-cell impairment in glutamate receptor 2 mutant mice. J Neurosci 22:RC204. Medline 